\title{
Formulation of growth and mortality of larval northern anchovy in a turbulent feeding environment
}

\author{
J. S. Wroblewski* \\ Department of Oceanography, Dalhousie University, Halifax, Nova Scotia B3H 4J1, Canada
}

\begin{abstract}
A simple model formalizes present ideas concerning the biological and physical oceanographic processes which may influence growth and survival of larvae of the northern anchovy Engraulis mordax. The model simulates the distribution of prey in a turbulent water column. Scale analysis is used to deduce the thickness of the food layer which can be maintained in the face of turbulent dissipation and zooplankton grazing pressure. Decrease in growth rate of anchovy larvae as the prey patch erodes results in a higher mortality rate, which is expressed as a function of feeding history of the larvae. Prey patches which increase in concentration enhance larvae survival. The magnitude of vertical turbulent diffusion in the mixed layer is related to wind speed. Its effectiveness in dispersing food for anchovy larvae can be altered by any ability of the prey to aggregate into patches.
\end{abstract}

\section{INTRODUCTION}

Momentum is building up in fisheries research for a concerted investigation into those mechanisms that link variations of environmental factors with fluctuations in recruitment (Rothschild and Rooth, 1982). The role of modeling in this research effort is to synthesize what we presently know from laboratory experiments and field observations into a theoretical basis for further hypothesis testing. Models over a wide range of complexity are needed to identify and quantify the importance of these mechanisms (Wroblewski, 1983).

The purpose of developing the present model is to formulate in simplest terms the present paradigm regarding the influence of the feeding environment on survival of the larval northern anchovy. Insight gained from this simple model will help interpret results from more realistic but complex models of larval fish growth and mortality presently being constructed.

Hjort was one of the first (1914) to propose that the phase in the life history of fishes which determined recruitment was the larval period, specifically the time of first feeding. The duration of this critical period has been broadened to include the first few weeks of life

\footnotetext{
- Present address: Bigelow Laboratory for Ocean Sciences, West Boothbay Harbor, Maine 04575, USA
}

until the larvae have metamorphosed, whereupon they are less susceptible to horizontal advection and vertical turbulence. It is now also recognized that predation rather than physiological death by starvation is the major cause of larval mortality, although the nutritional state and growth rate of the larvae determine their susceptibility to predation. Mortality during the post larval and juvenile stages will also affect recruitment, and therefore environmental influences upon these later stages cannot be neglected (Rothschild and Rooth, 1982). Physical-biological models which investigate the mechanisms influencing mortality of post larvae and juveniles will undoubtedly be built when sufficient observational and experimental data for these stages become available.

However, we shall confine the present modeling investigation to the critical larval stage, for a theory (originating from Lasker's observations in 1975, and commonly referred to as Lasker's hypothesis) is developing concerning the biological and physical oceanographic processes which influence survival at this stage of development. The fish species chosen for this modeling study is the northern anchovy Engraulis mordax, one of the few species for which there have been extensive field and laboratory investigations of the factors influencing larval mortality. Storms and upwelling events were found to disrupt food aggrega- 
tions off the California coast, and it was inferred that this may result in high mortality of the larvae (Lasker, 1975, 1978, 1981; Lasker and Smith, 1977; Lasker and Zweifel, 1978; Smith and Lasker, 1978). The ultimate cause of death is again probably not starvation, but rather predation on the weakened larvae by gelatinous zooplankton, carnivorous arthropods or adult fish (Hunter, 1982). Thus physical oceanographic features which act to aggregate or dissipate patches of the larvae's food are of obvious importance.

Parrish et al. (1981) have examined the effect of wind driven Ekman transport on large-scale larval drift of the northern anchovy, and Walsh et al. (1980) have speculated on the effect of large scale ecosystem changes on the survival of the Peruvian anchovy. Looking at the microscale, Vlymen (1977) and Lasker and Zweifel (1978) have built random-encounter models to simulate anchovy feeding on local food patches. But these authors did not specify the role of physical oceanographic processes in determining the food densities necessary for larval survival. Moreover, the dual effect of storms on dispersing the larvae's food in the vertical dimension while enhancing the overall productivity of the water column by entraining new nutrients from below the mixed layer has not been examined as yet. The former effect will be investigated here, deferring the more complex effect of enhancement of overall water column productivity for later investigation with an ecosystem model (Wroblewski and Richman, in prep.).

We are then interested in physical and biological features in the water column on a scale of $10 \mathrm{~m}$ in the vertical dimension, and in how these features vary over periods of hours to a day or two. We examine the physical and biological structure in the mixed layer by constructing a simple 1-dimensional, time-dependent $(\mathrm{z}, \mathrm{t})$ prey patchiness model for which there are analytical solutions. Any significant advection in the horizontal dimension is neglected. Our goal is to relate storm events to survival of larval fish by modeling the links between the cause (wind-driven, vertical dissipation of food patches) and the effect (higher mortality of slow growing larvae). We do not specify whether death is by starvation or enhanced predation on weakened larvae.

\section{SCALE ANALYSIS}

Scale analysis can be used to determine the significance of various factors which could be imagined $a$ priori to be important to the problem. For example, if the fish larvae eat dinoflagellates during their first feeding (Lasker et al., 1970) and the dinoflagellates migrate vertically, then we should consider the ability of these phytoplankton to aggregate in the mixed layer in the face of turbulence. Dinoflagellates can also photosynthesize and increase their concentration locally by cell division. Their concentration may be reduced by the grazing of various zooplankton predators. We might then write an equation for the vertical distribution of dinoflagellates

$\frac{\partial \mathrm{P}}{\partial \mathrm{t}}+\mathrm{w}_{\mathrm{s}} \frac{\partial \mathrm{P}}{\partial \mathrm{z}}-\frac{\partial}{\partial \mathrm{z}}\left(\mathrm{K}_{\mathrm{v}} \frac{\partial \mathrm{P}}{\partial \mathrm{z}}\right)=\mathrm{V}_{\mathrm{m}} \mathrm{P}-\mathrm{R}_{\mathrm{m}}\left(\mathrm{l}-\mathrm{e}^{-\lambda \mathrm{P}}\right)$

where the first term on the left hand side represents the local change in prey concentration $\mathrm{P}$, the second term represents vertical migration by the prey with a swimming speed $\mathrm{w}_{\mathrm{s}}$, and the third term represents turbulent mixing of $P$, where $K_{v}$ = vertical eddy diffusion coefficient. The first term on the right hand side of Equation (1) represents growth of $P$, where $V_{m}=$ maximum rate of increase of the prey. The last term represents losses due to zooplankton grazing. Parameter $R_{m}$ is the maximum grazing ration with units of concentration per second, and $\lambda$ is the Ivlev (1955) constant.

If the prey of the anchovy larvae were nonmigrating dinoflagellates or microzooplankton (e.g. copepod nauplii, ciliates and tintinnids) which have little ability to aggregate, Equation (1) could be rewritten without the vertical migration term. As we are interested in the distribution of prey in the surface mixed layer, we can assume $\mathrm{K}_{\mathrm{v}}$ is a constant. Equation (1) then becomes

$$
\frac{\partial \mathrm{P}}{\partial \mathrm{t}}=\mathrm{K}_{\mathrm{v}} \frac{\partial^{2} \mathrm{P}}{\partial \mathrm{z}^{2}}+\mathrm{V}_{\mathrm{m}} \mathrm{P}-\mathrm{R}_{\mathrm{m}}\left(1-\mathrm{e}^{-\lambda \mathrm{P}}\right)
$$

We will consider prey which have an ability to migrate later in this paper.

Equation (2) is analogous to the equation analyzed by Wroblewski et al. (1975) in deriving the minimum phytoplankton patch size which can be maintained by local growth in spite of turbulent diffusion and grazing. The only difference here is that the patch occurs in the vertical rather than the horizontal dimension, and a threshold in the grazing term has been dismissed.

We can gain insight into the processes involved in Equation (2) by converting the equation to nondimensional form. Let us scale time relative to the local growth rate of the prey by setting $\tau=V_{m} t$, where $\tau=$ nondimensional time; $\mathrm{V}_{\mathrm{m}}=$ growth rate of $\mathrm{P}$ (either nonmigrating dinoflagellates or microzooplankton). Let the local concentration of prey be scaled by the Ivlev grazing constant $\lambda$. And finally let us scale the vertical dimension by the ratio $\left(\mathrm{K}_{\mathrm{v}} / \mathrm{V}_{\mathrm{m}}\right)^{1 / 2}$. Substituting the relationships

$$
\begin{aligned}
\mathrm{V}_{\mathrm{m}} \mathrm{t} & =\tau \\
\lambda \quad \mathrm{P} & =\mathrm{P}^{\prime} \\
\text { and } \quad \mathrm{z} & =\mathrm{z}^{\prime}\left(\mathrm{K}_{\mathrm{v}} / \mathrm{V}_{\mathrm{m}}\right)^{1 / 2}
\end{aligned}
$$

(where primes denote dimensionless quantities) into Equation (2), we find 


$$
\frac{\partial \mathrm{P}^{\prime}}{\partial \tau}=\frac{\partial \mathrm{P}^{\prime}}{\partial \mathrm{z}^{\prime 2}}+\mathrm{P}^{\prime}-\alpha\left(1-\mathrm{e}^{-\mathrm{P}^{\prime}}\right)
$$

where the dimensionless parameter $\alpha=\lambda \mathrm{R}_{\mathrm{m}} / \mathrm{V}_{\mathrm{m}}$.

Wroblewski et al. (1975) found an analytical solution to Equation (3) for cases where P' was a small quantity, but they also showed the solutions were only valid for the initial response of the patch to turbulent dissipation and grazing. In order to achieve realistic solutions for periods longer than $2 \mathrm{~d}$, they concluded it was necessary to include nutrient limitation of phytoplankton growth (or food limitation of microzooplankton growth), keeping $\mathrm{P}^{\prime}$ relatively small as in nature. Nevertheless it is instructive to examine the solutions for this simplified model.

The solution to Equation (3) for an initial $\mathrm{P}^{\prime} \ll 1$ and the initial condition $\mathrm{P}^{\prime}\left(\mathrm{z}^{\prime}, 0\right)=\mathrm{A} \cos (2 \pi \mathrm{kz})$ is

$$
\mathrm{P}^{\prime}\left(\mathrm{z}^{\prime}, \tau\right)=\mathrm{A} \mathrm{e}^{-\left[(2 \pi \mathrm{k})^{2}-(1-\alpha)\right] \tau} \cos (2 \pi \mathrm{kz})
$$

where $\mathrm{A}=$ an arbitrary initial patch amplitude; $\mathrm{k}=$ wavenumber. Thus if

$$
(2 \pi \mathrm{k})^{2}-(1-\alpha)<0,
$$

all prey patches with size $\mathrm{k}^{-1}$ will grow. If the patch's wavenumber is the critical wavenumber

$$
\mathrm{k}_{\mathrm{c}}=\frac{1}{2 \pi}(1-\alpha)^{1 / 2},
$$

the patch will neither grow nor decrease in size. In dimensional terms

$$
\mathrm{k}_{\mathrm{c}}^{*}=\frac{1}{2 \pi}\left(\frac{1-\alpha}{\mathrm{K}_{\mathrm{v}} / \mathrm{V}_{\mathrm{m}}}\right)^{1 / 2}
$$

When $\alpha=0$, we have the classical Kierstead and Slobodkin (1953) solution. Since $\alpha=R_{m} \lambda / V_{m}$, the modified critical length scale may be written

$$
\mathrm{H}_{\mathrm{c}}=2 \pi\left(\frac{\mathrm{K}_{\mathrm{v}}}{\mathrm{V}_{\mathrm{m}}-\mathrm{R}_{\mathrm{m}} \lambda}\right)^{1 / 2}
$$

where we use $\mathrm{H}_{c}$ to denote the critical thickness scale in the vertical domain. Only if $\mathrm{H}>\mathrm{H}_{\mathrm{c}}$ can the patch grow fast enough to avoid being dispersed by diffusion. The effect of $\alpha$ is to shift the critical patch thickness to a larger value. Notice that if $\alpha \geq 1$, all patches will decay. This is intuitively obvious, for $\alpha$ is in effect the ratio of the grazing loss to the growth rate.

Let us evaluate $\mathrm{H}_{\mathrm{c}}$ for parameter values pertinent to a chlorophyll layer observed in Coyote Bay (Lat. $26^{\circ} 43.0^{\prime} \mathrm{N}$, Long. $111^{\circ} 53.0^{\prime} \mathrm{W}$ ) of Bahia Concepcion, Gulf of California by Kiefer and Lasker (1975). The chlorophyll layer was composed mostly of Gymnodinium splendens, a suitable prey for young anchovy larvae (Lasker et al., 1970). Wind conditions were calm and the shallow water column was isothermal with depth. Kiefer and Lasker (1975) estimated a doubling time of about $2.5 \mathrm{~d}$ for cells in the layer. However their estimate includes various losses (e.g. grazing) from the cell population. In the laboratory Thomas et al. (1973) measured a maximum doubling time of $1.6 \mathrm{~d}$ for $G$. splendens. Since $\mathrm{V}_{\mathrm{m}}=1 \mathrm{n} 2 /$ doubling time, the appropriate maximum growth rate of the dinoflagellates is $0.43 \mathrm{~d}^{-1}$ or $5 \times 10^{-6} \mathrm{~s}^{-1}$. Based on the difference in doubling time estimates from the field and laboratory, we can assume the grazing rate $R_{m} \lambda$ was of order $50 \% \mathrm{~V}_{\mathrm{m}}$. Under calm wind conditions, $\mathrm{K}_{\mathrm{v}}$ in the mixed layer can be of the order $10^{-2}$ to $1 \mathrm{~cm}^{2} \mathrm{~s}^{-1}$. Any layer of passive prey with thickness less than $40 \mathrm{~m}$ (the value of $\mathrm{H}_{\mathrm{c}}$ ) would have been dispersed by winds generating a vertical diffusivity of $1 \mathrm{~cm}^{2} \mathrm{~s}^{-1}$.

The chlorophyll maximum observed by Kiefer and Lasker (1975) was about $5 \mathrm{~m}$ in vertical extent, which is clearly thinner than the layer thickness $\mathrm{H}_{\mathrm{c}}$ which could be maintained by growth over turbulent dissipation and grazing. However a chlorophyll maximum of $5 \mathrm{~m}$ thickness would just be maintained if the vertical diffusivity were only $0.1 \mathrm{~cm}^{2} \mathrm{~s}^{-1}$. Alternatively, if the dinoflagellates were able to aggregate in the mixed layer (and Gymnodinium splendens has this ability), this would lower the effective value of $\mathrm{K}_{\mathrm{v}}$. The critical vertical scale would be decreased and the chlorophyll layer maintained. The reader can insert any combination of values for effective $K_{v}, V_{m}, \lambda$ and $R_{m}$ into the equation for $\mathrm{H}_{\mathrm{c}}$ to see how the critical patch thickness changes with these alternative parameter values.

\section{NUMERICAL SOLUTION OF THE MODEL}

To illustrate the dynamics of the model, we can express Equation (3) in finite difference form (see Wroblewski et al., 1975 for details) and solve the model numerically. Fig. 1 shows the solution of Equation (3) for $\tau=0,1$ and 3 . As $V_{m}$ is approximately $0.5 \mathrm{~d}^{-1}, \tau=$ 1 and 3 corresponds to 2 and 6 d respectively. Six days are beyond the time for which the model is valid, but examining $\tau=3$ gives the reader an idea of the longer term model response. As depth is scaled by $\left(\mathrm{K}_{\mathrm{v}} / \mathrm{V}_{\mathrm{m}}\right)^{1 / 2}$, if $\mathrm{V}_{\mathrm{m}}=5 \times 10^{-6} \mathrm{~s}^{-1}$ and $\mathrm{K}_{\mathrm{v}}=0.1 \mathrm{~cm}^{2} \mathrm{~s}^{-1}$, the depth range is 0 to $42 \mathrm{~m}$. The initial patch thickness is $\mathrm{k}^{-1}=8.9 \mathrm{~m}$. The layer of chlorophyll is spread out vertically by diffusion and reduced in concentration by intense zooplankton grazing, as we have assumed $\alpha=1.5$ to illustrate this case. For simplicity, the grazers are assumed to be homogeneously distributed throughout the mixed layer, so there is no spatial dependence in $\alpha$.

As we are interested in how the concentration of prey $\mathrm{P}$ influences larval fish mortality, we must now formulate the feeding dynamics of larval northern anchovy. Most of the feeding experiments on larval 


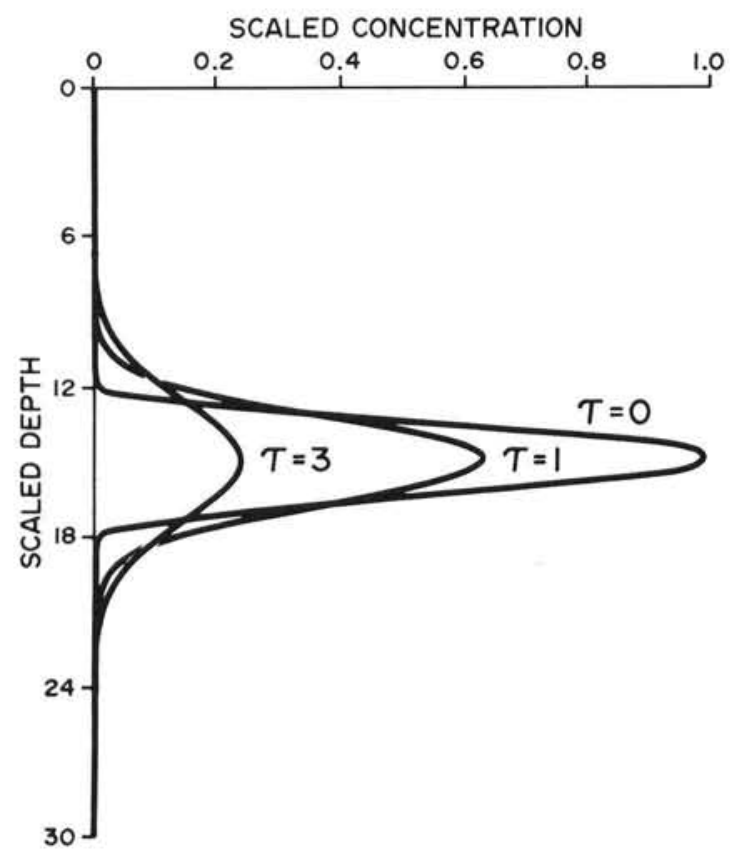

Fig. 1. Dissipation of an initial patch of prey with nondimensional time. The highest scaled concentration occurs at the initial time $\tau=0$. The distribution of prey spreads in the vertical dimension and the concentration decreases due to diffusion and intense zooplankton grazing

Engraulis mordax found in the literature use microzooplankton as prey rather than dinoflagellates. We must therefore use growth rates from these laboratory experiments to estimate the minimal food requirements (in terms of nitrogen) of young larvae.

Although Lasker (1975) argues that the dinoflagellate Gymnodinium splendens is important in the diet of first feeding anchovy larvae, it is also known that dinoflagellates will not support larvae older than $20 \mathrm{~d}$ (Lasker et al., 1970). The diet of these older larvae switches to microzooplankton, i.e. small crustaceans, ciliates and tintinnids, with only a small fraction of phytoplankton (Hunter and Thomas, 1974; Arthur, 1976). The generation time of microzooplankton is in the order of hours to days (Pomeroy, 1974; Sheldon and Sutcliffe, Jr., 1978; and others) with values of $V_{m}$ within the same order of magnitude as dinoflagellates. There is even some evidence that microzooplankton occur in patches (Owen, 1981) and may be associated with the chlorophyll maximum (Beers and Stewart, 1970; Chester, 1978). Thus our calculations are not much different whether the prey variable $\mathrm{P}^{\prime}$ in Equation (3) is dinoflagellates or microzooplankton, as long as the nutritional quality of the prey is sufficient (Lasker, 1981).

From feeding experiments performed by O'Connell and Raymond (1970) the maximum growth rate of larval anchovy appears to be $22 \%$ per day. We know that

$$
\text { growth }=\text { ingestion - egestion - excretion. }
$$

Ingestion R of prey by larval fish is calculated from the Ivlev (1955) expression

$$
\mathrm{R}=\mathrm{R}_{\mathrm{F}}\left(1-\mathrm{e}^{-\mathrm{cP}}\right)
$$

where $\mathrm{P}=$ prey concentration; $\mathrm{R}_{\mathrm{F}}=$ maximum ingestion rate; $\mathrm{c}=$ Ivlev constant.

Egestion of fecal matter by anchovy larvae is taken to be a constant fraction $\delta$ of the ingested ration R. Thus

egestion $=\delta$ R.

As a first approximation, metabolic excretion of nitrogen is assumed to occur at a constant basal rate, $\varepsilon$, plus an additional metabolic excretion associated with feeding activity, $\gamma$ R. Thus

$$
\text { excretion }=\gamma \mathrm{R}+\varepsilon \text {. }
$$

Therefore

$$
\begin{aligned}
\text { growth } & =\mathrm{R}_{\mathrm{F}}\left(1-\mathrm{e}^{-c \mathrm{P}}\right)-\delta \mathrm{R}_{\mathrm{F}}\left(1-\mathrm{e}^{-c P}\right)-\gamma \mathrm{R}_{\mathrm{F}}\left(1-\mathrm{e}^{-c \mathrm{P}}\right)-\varepsilon \\
& =\mathrm{R}_{\mathrm{F}}(1-\delta-\gamma)\left(1-\mathrm{e}^{-c \mathrm{P}}\right)-\varepsilon .
\end{aligned}
$$

The assimilation efficiency $(1-\delta-\gamma)$ is lower in larval clupeoids than in juveniles and adults due to immaturity of the digestive system (Blaxter and Hunter, 1982). Houde and Schekter (1981) found assimilation efficiencies between 24 and $41 \%$ for bay anchovy. Based on data presented in Vlymen (1977) and Lasker et al. (1970), we choose $\delta=0.4$. Very little information on nitrogen excretion by anchovy larvae is available. Using Weihs (1980) as a guide, we assume the basal metabolic excretion parameter $\varepsilon$ is $5 \% \mathrm{~d}^{-1}$ and the metabolic excretion parameter associated with feeding, $\gamma_{1}$ is $20 \%$ of $R_{F}$. The assimilation efficiency $(1-\delta-\gamma)$ is then $40 \%$, which is consistent with the findings of Houde and Schekter (1981).

The maximum growth rate of $22 \% \mathrm{~d}^{-1}$ measured by O'Connell and Raymond (1970) occurs when ingestion is maximal, i.e. when $R=R_{F}$. Thus

$$
\begin{aligned}
0.22 \mathrm{~d}^{-1} & =\mathrm{R}_{\mathrm{F}}(1-\delta-\gamma)-\varepsilon \\
& =\mathrm{R}_{\mathrm{F}}(0.4)-0.05 \mathrm{~d}^{-1} .
\end{aligned}
$$

Solving for $\mathrm{R}_{\mathrm{F}}$

$$
\text { or } \begin{aligned}
0.27 \mathrm{~d}^{-1} & =0.4 \mathrm{R}_{\mathrm{F}} \\
0.68 \mathrm{~d}^{-1} & =\mathrm{R}_{\mathrm{F}} .
\end{aligned}
$$

The value of $R_{F}$ represents a daily average. As larval fish are visual feeders, $R_{F}$ may be much higher during the day and near zero at night. An $R_{F}$ value of about 3 times the maximum growth rate seems reasonable. Laurence (1977) found a similar value for larvae of winter flounder Pseudopleuronectes americanus.

Based on the feeding experiments by $\mathrm{O}^{\prime} \mathrm{Connell}$ and Raymond (1970), the Ivlev constant c for larval anchovy is about $2\left(\mu \mathrm{g} \text { atom } \mathrm{N}^{-1}\right)^{-1}$. That is, the feeding rate is ${ }^{2} / 3 \mathrm{R}_{\mathrm{F}}$ at a prey concentration about $0.5 \mu \mathrm{g}$ atom $\mathrm{N}^{-1}$, 


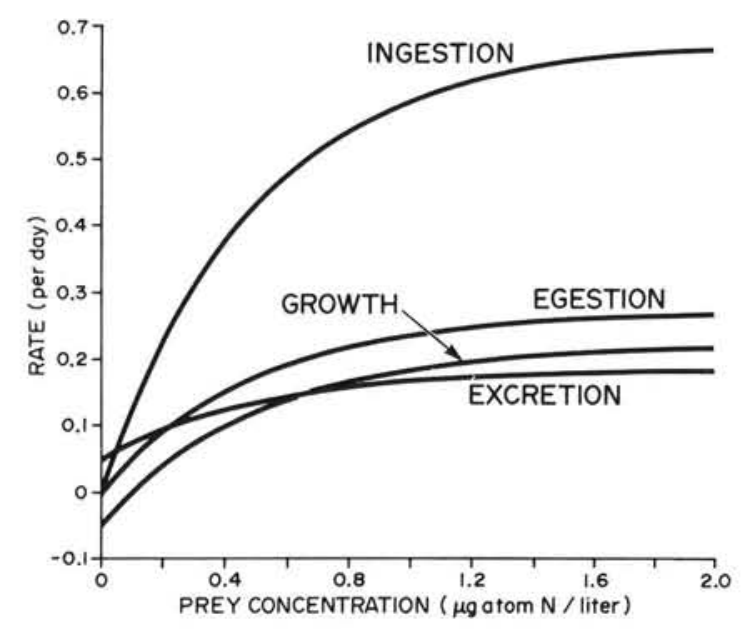

Fig. 2. Engraulis mordax, larvae. Rates of ingestion, egestion, excretion and growth with increasing concentration of prey. A prey concentration of $0.44 \mu \mathrm{g}$ atom $\mathrm{N}^{-1}$ is equivalent to about 1 copepod nauplius $\mathrm{ml}^{-1}$. (Based on data in $\mathrm{O}^{\prime}$ Connell and Raymond, 1970)

which is about 1 copepod nauplius $\mathrm{ml}^{-1}$. Fig. 2 shows a plot of ingestion, egestion, excretion and growth of northern anchovy larvae as a function of prey concentration for these parameter values.

Careful formulation of larval mortality as a function of prey concentration must now be included if we are to understand the environmental conditions which influence survival of young anchovy. Larval mortality is assumed to be a function of weight at age, or in other words, a function of the feeding history of the larvae. Larval weight is expressed as

$$
\mathrm{W}=\mathrm{W}_{\mathrm{o}} \mathrm{e}^{\frac{\mathrm{t}}{\mathrm{L}} \mathrm{G} \Delta \mathrm{t}}
$$

where $\mathrm{W}_{\mathrm{o}}=$ initial weight of the larvae at time $\mathrm{t}=0$; growth rate $\mathrm{G}$ of the larvae = difference between ingestion and egestion plus excretion. Larval mortality $M$ is then expressed as a function of the baseline growth rate $\mathrm{r}$ and the actual value of $\mathrm{W}$,

$$
M=f\left(\frac{e^{r t}}{W / W_{o}}\right)
$$

so that if $G>r$, larval mortality will decrease over time; if $\mathrm{G}<\mathrm{r}$, mortality will increase over time; and if $\mathrm{G}=\mathrm{r}$, mortality will be constant. Beyer and Laurence (1980) also used a baseline growth rate when formulating mortality in a stochastic model of larval fish survival. The function $f$ is assumed to be a power function, i.e.

$$
\begin{aligned}
M & =a\left(\frac{e^{r t}}{W / W_{o}}\right)^{b} \\
& =a\left(e^{\frac{t}{\Sigma}(r-G) \Delta t}\right)^{b} .
\end{aligned}
$$

To estimate the mortality parameters $\mathrm{a}, \mathrm{b}$ and $\mathrm{r}$ we must again turn to the experiments by $\mathrm{O}^{\prime}$ Connell and Raymond (1970). These authors present data on numbers of surviving larvae and their weights over time at different food concentrations. A multiple linear regression analysis was conducted to estimate $\mathrm{a}, \mathrm{b}$ and $\mathrm{r}$ in the equation

$$
\ln \mathrm{M}=\ln \mathrm{a}+\mathrm{brt}-\mathrm{b} \ln \left(\mathrm{W} / \mathrm{W}_{\mathrm{o}}\right) .
$$

It was found that $a$ is $6 \% \mathrm{~d}^{-1}, \mathrm{~b}$ is 2.12 and $\mathrm{r}$ is $17.5 \%$ $\mathrm{d}^{-1}$. Thus if a population of similar larvae grows at the baseline rate of $17.5 \% \mathrm{~d}^{-1}$, the mortality rate of the population will be constant at $6 \% \mathrm{~d}^{-1}$. If the growth rate is higher, then mortality will decrease over time, and if the growth rate is lower, mortality will increase over time (Fig. 3).

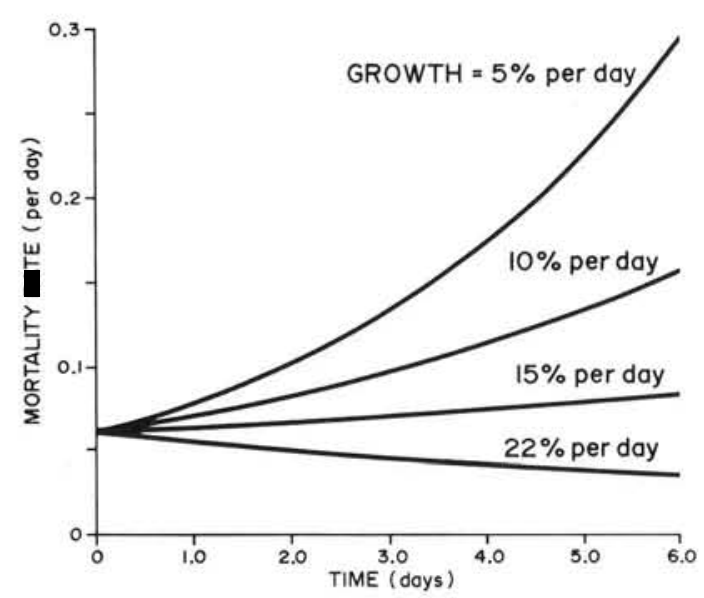

Fig. 3. Engraulis mordax, larvae. Rate of mortality with time for different constant growth rates. (Based on formulation of mortality rate described in the text and parameter values derived from data in O'Connell and Raymond, 1970)

Before we can incorporate these physiological dynamics for northern anchovy larvae into the prey patchiness model, we must scale the equation

$\frac{\partial F}{\partial t}=R_{F}(1-\delta-\gamma)\left(1-e^{-c P}\right) F-\varepsilon F-a\left(e^{\frac{1}{\Sigma}(r-G) \Delta t}\right)^{b} F$

where $\mathrm{F}$ is the concentration of larval anchovy biomass.

Again let $\mathrm{V}_{\mathrm{m}} \mathrm{t}=\tau$ and $\lambda \mathrm{P}=\mathrm{P}^{\prime}$. Now let $\lambda \mathrm{F}=\mathrm{F}^{\prime}$. Then Equation (4) becomes

$$
\begin{aligned}
& \frac{\partial F^{\prime}}{\partial \tau}=\frac{R_{F}}{V_{m}}(1-\delta-\gamma)\left(1-e^{-\frac{c}{\lambda} P^{\prime}}\right) F^{\prime}-\frac{\varepsilon}{V_{m}} F^{\prime}- \\
& \frac{a}{V_{m}}\left(e^{\frac{\tau}{2}} \frac{(r-G)}{V_{m}}\right)^{b} F .
\end{aligned}
$$

The only additional parameter we must now specify is $\mathrm{c} / \lambda$, the ratio of the Ivlev constants for larval fish grazing and total zooplankton grazing. We choose this ratio to be order one. With this value, changes in the scaled prey concentration $\mathrm{P}^{\prime}$ from the maximum con- 


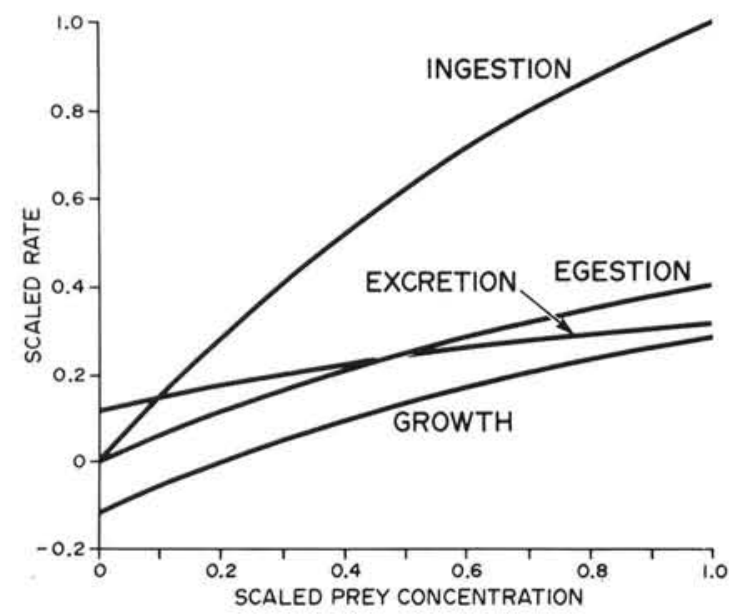

Fig. 4. Same as Fig. 2 except rates and prey concentration have been scaled into nondimensional quantities as described in the text

centration $\left(\mathrm{P}^{\prime}=1.0\right)$, either by turbulent diffusion or growth of $\mathrm{P}^{\prime}$, will have a noticeable effect on the growth and mortality of the anchovy larvae (Fig. 4). Higher values for $\mathrm{c} / \lambda$ would increase the steepness of the curves in Fig. 4, decreasing the sensitivity of the fish larvae to changes in $\mathrm{P}^{\prime}$.

\section{MODEL RESULTS}

Knowing larval growth and mortality as a function of prey concentration, we can plot in Fig. 5 the depth distribution of these rates over time as the prey patch shown in Fig. 1 dissipates. It is assumed the anchovy larvae are homogeneously distributed within the mixed layer. For a simplified model this is a defensible assumption, and observations show this is often the case (Blaxter and Hunter, 1982). It is also assumed that the young anchovy larvae do not migrate vertically. We can neglect the larval fish biomass as a contributor to the grazing stress on P' because larval fish make up such a small fraction of the total zooplankton biomass. While larval fish feeding does not affect the concentration of P' (Cushing, 1983), the converse is not true, of course. We see that the highest growth rate (Fig. $5 \mathrm{~A}$ ) and lowest mortality rate (Fig. 5 B) of anchovy larvae occur at the center of the prey patch.

At the heart of Lasker's (1975) hypothesis is the idea that vertical mixing during wind events will dissipate the prey patch to varying degrees, leading to fluctuations in mortality of larval anchovy. Therefore we must investigate the response of the model to increasing values of the vertical diffusivity coefficient $\mathrm{K}_{\mathrm{v}}$. Fig. 6 shows the scaled mortality rate for fish larvae positioned at the same depth as the maximum in $\mathrm{P}^{\prime}$ as the patch decays over $2 \mathrm{~d}$. One can alter the value of $\mathrm{K}_{\mathrm{v}}$ in the model by varying the patch wavenumber $\mathrm{k}$. Now $\mathrm{z}=\mathrm{z}^{\prime}\left(\mathrm{K}_{\mathrm{v}} / \mathrm{V}_{\mathrm{m}}\right)^{1 / 2}$ where $\mathrm{z}=$ initial patch thickness; $\mathrm{z}^{\prime}=$ $1 / \mathrm{k}$. If $\mathrm{z}$ is fixed at $8.9 \mathrm{~m}$ and $\mathrm{V}_{\mathrm{m}}$ is fixed at $5 \times 10^{-6} \mathrm{~s}^{-1}$, then for $\mathrm{K}_{\mathrm{v}}=0.1 \mathrm{~cm}^{2} \mathrm{~s}^{-1}, \mathrm{k}=1 /(2 \pi)$; for $\mathrm{K}_{\mathrm{v}}=0.4 \mathrm{~cm}^{2}$ $\mathrm{s}^{-1}, \mathrm{k}=1 / \pi$; and for $\mathrm{K}_{\mathrm{v}}=1.6 \mathrm{~cm}^{2} \mathrm{~s}^{-1}, \mathrm{k}=2 / \pi$.

The family of curves in Fig. 6 shows that for increasing values of $K_{v}$, the scaled mortality rate increases exponentially.

We can also investigate the response of the model where the patch grows. Earlier we derived the critical wavenumber

$$
\mathrm{k}_{\mathrm{c}}=\frac{1}{2 \pi}(1-\alpha)^{1 / 2} .
$$

If $\alpha>1.0$, the patch must decay, for the grazing ration is greater than the daily production by the prey. If $\alpha=$ 1 , prey production equals loss to predation and the only losses from the patch are due to turbulent diffusion (Fig. 6, curves A, B and C). But now if $\alpha=0$, the

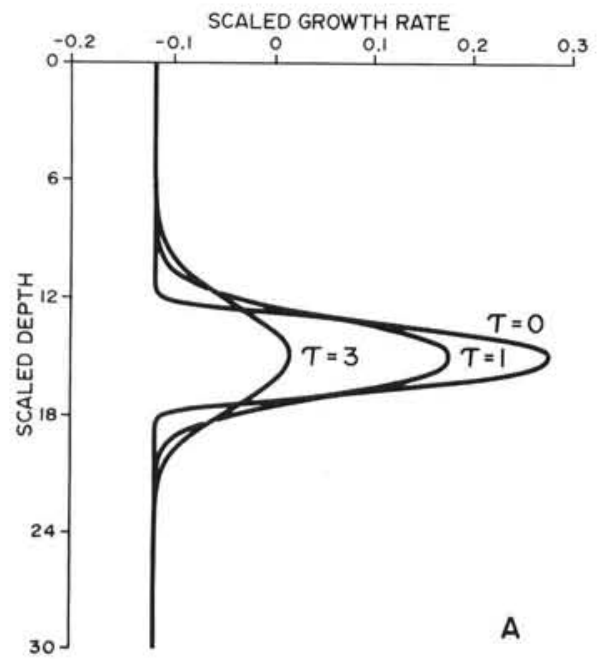

A

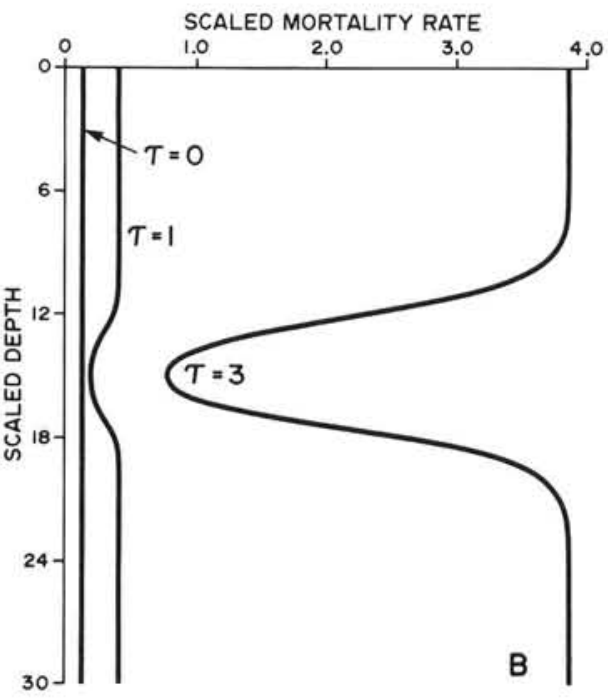

Fig. 5. Engraulis mordax, larvae, (A) Scaled growth rate with nondimensional time and scaled depth for prey distributions shown in Fig. 1. Nondimensional time $\tau$ $=1$ corresponds to $2 \mathrm{~d}$, and $\tau=3$ corresponds to $6 \mathrm{~d}$ elapsed from time zero. (B) Scaled mortality rate corresponding to the feeding history and growth rate depicted in Fig. $5 \mathrm{~A}$ 


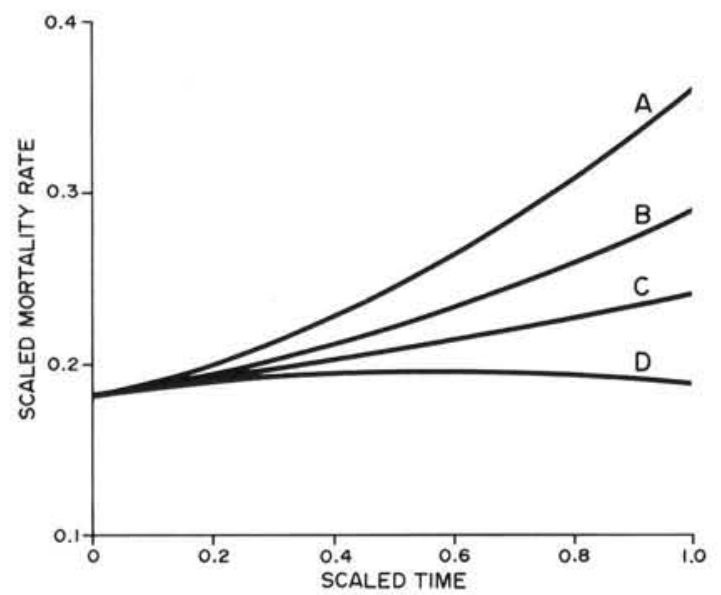

Fig. 6. Engraulis mordax, larvae. Scaled mortality rate in the center of the prey patch. For Curves A, B and C the prey patch dissipates. Parameter $\alpha=1.0$ and $\mathrm{K}_{\mathrm{v}}$ values are $1.6,0.4$ and $0.1 \mathrm{~cm}^{2} \mathrm{~s}^{-1}$ respectively. For Curve D, parameter $\alpha=0$ and $\mathrm{K}_{\mathrm{V}}$ is $0.1 \mathrm{~cm}^{2} \mathrm{~s}^{-1}$, so the prey patch grows

critical wavenumber is $1 /(2 \pi)$. All patches with a wavenumber greater than this value will grow. In Fig. 6 (Curve D) we plot the scaled larval anchovy mortality rate for a prey patch of initial thickness $\mathrm{k}^{-1}=8 \pi\left(\mathrm{K}_{\mathrm{v}}\right)$ $\left.\mathrm{V}_{\mathrm{m}}\right)^{1 / 2}=35.4 \mathrm{~m}$, assuming $\mathrm{K}_{\mathrm{v}}=0.1 \mathrm{~cm}^{2} \mathrm{~s}^{-1}$ and $\mathrm{V}_{\mathrm{m}}=5$ $\times 10^{-6} \mathrm{~s}^{-1}$. This patch will clearly grow. The increase over time of $\mathrm{P}^{\prime}$ at the patch center is shown in Fig. 7.

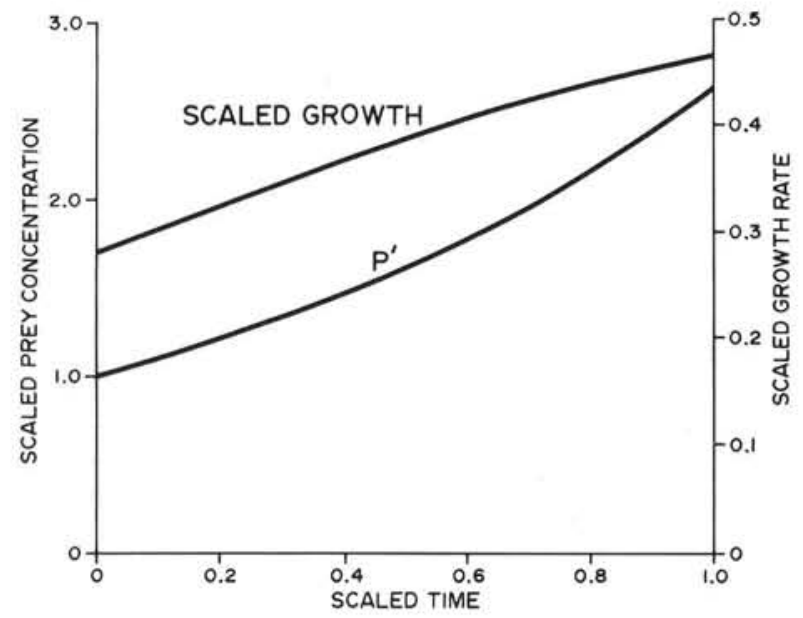

Fig. 7. Engraulis mordax, larvae. Scaled growth rate in the center of the prey patch which grows (Fig. 6, Curve D). Scaled concentration of $\mathrm{P}^{\prime}$ in patch center, as the patch grows over nondimensional time, is shown in the lower curve

This results in an increase in growth rate of the anchovy larvae and a decrease in the mortality rate once P' has reached a value of 1.75 , which occurs at $\tau=$ 0.6 . Thereafter the growth rate exceeds the baseline growth rate, resulting in a decrease in mortality rate (Fig. 6, Curve D). This rate will continue to plummet exponentially.

\section{Vertically migrating prey}

Thus far we have only considered the case where northern anchovy larvae feed on nonmigrating dinoflagellates or microzooplankton. The dinoflagellate Gymnodinium splendens reported in Lasker's (1975) observations does have a vertical swimming capability (Kiefer and Lasker, 1975), which can concentrate the larval anchovy's food into a layer if turbulence conditions permit. Scale analysis can again be used to determine the magnitude of the vertical diffusivity which just balances aggregation by the dinoflagellates.

Reconsider Equation (1) where the zooplankton grazing term has been expanded by Taylor series and all second order terms have been neglected so that

$$
\mathrm{R}_{\mathrm{m}}\left(1-\mathrm{e}^{-\lambda \mathrm{P}}\right) \approx \mathrm{R}_{\mathrm{m}} \lambda \mathrm{P} .
$$

We again only consider prey within the mixed layer where $\mathrm{K}_{\mathrm{v}}$ is a constant. Dinoflagellates can migrate through the thermocline to depths of reduced turbulence (Cullen and Eppley, 1981), but this situation is too complex for a first modeling attempt. Our basic equation is then

$$
\frac{\partial \mathrm{P}}{\partial \mathrm{t}}+\mathrm{w}_{\mathrm{s}} \frac{\partial \mathrm{P}}{\partial \mathrm{z}}-\mathrm{K}_{\mathrm{v}} \frac{\partial^{2} \mathrm{P}}{\partial \mathrm{z}^{2}}=\left(\mathrm{V}_{\mathrm{m}}-\mathrm{R}_{\mathrm{m}} \lambda\right) \mathrm{P} .
$$

Let us scale $\mathrm{P}$ by the total amount of dinoflagellates in the layer $\mathrm{P}_{\mathrm{T}}$, and depth $\mathrm{z}$ by the thickness of the layer $\mathrm{H}$. Since we are interested in the ability of the dinoflagellates to maintain the layer by swimming, let us scale time $\mathrm{t}$ by the ratio $\mathrm{H} / \mathrm{w}_{\mathrm{s}}$. Substituting the relations

$$
\begin{aligned}
\mathrm{t} & =\left(\mathrm{H} / \mathrm{w}_{\mathrm{s}}\right) \tau \\
\mathrm{P} & =\mathrm{P}^{\prime} \mathrm{P}_{\mathrm{T}} \\
\text { and } \quad \mathrm{z} & =\mathrm{z}^{\prime} \mathrm{H}
\end{aligned}
$$

(where primes denote nondimensional quantities) into Equation (6) we find,

$$
\frac{\partial \mathrm{P}^{\prime}}{\partial \tau}+\frac{\partial \mathrm{P}^{\prime}}{\partial \mathrm{z}^{\prime}}-\left[\frac{\mathrm{K}_{\mathrm{v}}}{\mathrm{H} \mathrm{w}_{\mathrm{s}}}\right] \frac{\partial^{2} \mathrm{P}^{\prime}}{\partial \mathrm{z}^{\prime 2}}=\frac{\mathrm{H}}{\mathrm{w}_{\mathrm{s}}}\left(\mathrm{V}_{\mathrm{m}}-\mathrm{R}_{\mathrm{m}} \lambda\right) \mathrm{P}^{\prime} .
$$

The nondimensional coefficient $\mathrm{K}_{\mathrm{v}} /\left(\mathrm{H} \mathrm{w}_{\mathrm{s}}\right)$ is instructive as it specifies the vertical diffusivity which just balances the dinoflagellates' ability to maintain the layer. If the diffusion term balances the vertical migration term,

$$
\mathrm{K}_{\mathrm{v}}=\mathrm{H} \mathrm{w}_{\mathrm{s}} \text {. }
$$

Let us evaluate this particular value of $\mathrm{K}_{\mathrm{v}}$. Kiefer and Lasker (1975) observed a chlorophyll layer approximately $5 \mathrm{~m}$ thick, composed mostly of Gynodinium splendens. The layer moved vertically at a speed of approximately $1 \mathrm{~m} \mathrm{~h}^{-1}$ in a diel migration. With this swimming speed the dinoflagellates should be able to maintain the layer against a diffusivity of $14 \mathrm{~cm}^{2} \mathrm{~s}^{-1}$. 
Dinoflagellates can also maintain their concentration locally by cell division. If the net growth term in Equation (7) just balanced losses due to diffusion alone,

$$
\mathrm{K}_{\mathrm{v}}=\mathrm{H}^{2}\left(\mathrm{~V}_{\mathrm{m}}-\mathrm{R}_{\mathrm{m}} \lambda\right) .
$$

As mentioned above, Kiefer and Lasker (1975) estimated a doubling time for the phytoplankton layer of about $2.5 \mathrm{~d}$. The net growth rate of the phytoplankton would then be $1 \mathrm{n} 2 / 2.5 \mathrm{~d}$ or $3.2 \times 10^{-6} \mathrm{~s}^{-1}$. Their estimate of a net growth rate would include losses due to grazing and approximates the term $\left(\mathrm{V}_{\mathrm{m}}-\mathrm{R}_{\mathrm{m}} \lambda\right)$ in Equation (6). Thus a layer of dinoflagellates $5 \mathrm{~m}$ thick could be maintained by this local net growth rate against a diffusivity of $\mathrm{K}_{\mathrm{v}}=0.8 \mathrm{~cm}^{2} \mathrm{~s}^{-1}$. The growth term is negligible compared to the vertical migration term in Equation (6).

These results from scale analysis indicate that food for larval anchovy can be maintained in a layer under moderate turbulence conditions if the prey has an ability to swim vertically. If the prey did not aggregate, the threshold for turbulent dissipation of the food would be much lower, as we have shown earlier.

Once the value of $K_{v}$ in the mixed layer exceeds this special value $\left(\mathrm{K}_{\mathrm{v}}=\mathrm{H} \mathrm{w}_{\mathrm{s}}\right)$ at which the dinoflagellates can just maintain the layer, the prey patch will erode. Okubo (1972) has derived analytical solutions for small organism diffusion around an attractive center which may be applicable. Under strong mixing conditions, even the ability of the prey to aggregate can be neglected. The effect of strong turbulent dissipation of the dinoflagellate layer upon larval anchovy survival would be similar to the model solutions shown earlier (with the proper scaling).

\section{Relation of $\mathrm{K}_{\mathrm{v}}$ to wind speed}

One would like to relate the value of the vertical diffusion coefficient $K_{\mathrm{v}}$ to a specific wind speed so that model predictions could be compared to observations of certain storm events. Vertical mixing in the surface layer of the sea may be related to the wind stress, density stratification in the surface layer and vertical shear of the current. Kullenberg (1971) suggested the scaling relation for the vertical eddy diffusivity,

$$
\mathrm{K}_{\mathrm{v}}=\mathrm{Rf} \frac{\tau_{\mathrm{o}}}{\mathrm{\varrho N}^{2}}|\mathrm{dq} / \mathrm{dz}|
$$

where $\tau_{\mathrm{o}}=$ wind stress; $\mathrm{N}^{2}=$ square of static stability frequency; $\varrho=$ density of seawater; $|\mathrm{dq} / \mathrm{dz}|=$ magnitude of vertical shear of the current; $\mathrm{Rf}=$ flux Richardson number (the ratio of the turbulent buoyancy flux to the rate of production of turbulent kinetic energy). In shallow water dye diffusion studies, Kul- lenberg (1971) found reasonable agreement between the dispersion of the injected dye and the formula above, evaluated for the depth where the layer of dye was located. Using energy transfer arguments and assuming a turbulent Ekman layer, Kullenberg (1976) simplified this relation to obtain a simple formula for the rate of vertical mixing generated by the wind,

$$
\mathrm{K}_{\mathrm{m}}=4 \times 10^{-5} \mathrm{~W}_{10}^{2}
$$

where $\mathrm{K}_{\mathrm{m}}=$ vertical momentum transfer coefficient; $\mathrm{W}_{10}=$ wind speed at $10 \mathrm{~m}$ above sea surface. The ratio $\mathrm{K}_{\mathrm{v}} / \mathrm{K}_{\mathrm{m}}$ is proportional to $\mathrm{Ri}^{-1}$, where $\mathrm{Ri}=$ gradient Richardson number. Thus one cannot simply relate $\mathrm{K}_{\mathrm{v}}$ to wind speed without some knowledge of the physical structure of the water column. Unfortunately, Lasker (1975) did not report the local wind speed or the detailed hydrography needed to relate the observed dispersion of the chlorophyll layer on April 9, 1974 at Lat. $33^{\circ} 19.9^{\prime} \mathrm{N}$, Long. $117^{\circ} 35.3^{\prime} \mathrm{W}$ to a specific value of $\mathrm{K}_{\mathrm{v}}$.

However, Lasker (1978) does present typical temperature profiles for the California coastal region between November, 1974 and April, 1975. The chlorophyll layer observed by Lasker in April, 1974 was probably located near the base of the mixed layer in the vicinity of the nitracline (Cullen and Eppley, 1981). For a mixed layer depth of $20 \mathrm{~m}$, an ambient stratification of $3 \mathrm{cph}$ (i.e. $10^{-3} \mathrm{~s}^{-1}$ ) and a wind stress of 1 dyne $\mathrm{cm}^{-2}$, $\mathrm{Ri}$ is about 4 . Thus $\mathrm{K}_{\mathrm{v}} / \mathrm{K}_{\mathrm{m}}$ is approximately 0.05 (Fig. $1 \mathrm{~b}$ in Kullenberg, 1978). If the stratification were less, the ratio would be closer to unity. Using the estimate

$$
\mathrm{K}_{\mathrm{v}}=0.05 \mathrm{~K}_{\mathrm{m}}=2 \times 10^{-6} \mathrm{~W}_{10}^{2}
$$

a wind speed of $26 \mathrm{~m} \mathrm{~s}^{-1}$ would result in a turbulent diffusivity of $14 \mathrm{~cm}^{2} \mathrm{~s}^{-1}$. This is the particular value of $\mathrm{K}_{\mathrm{v}}$ calculated earlier where the motile dinoflagellates can just maintain the layer. Any higher wind speed would dissipate the vertical structure in the dinoflagellate distribution. Lasker (1975) did report that the storm that obliterated the chlorophyll layer on April 9, 1974 was violent.

\section{LIMITATIONS OF THE MODEL}

Future versions of this model will include physical dynamics of wind and water column so as to simulate wind-driven, mixing events in more detail. As anchovy larvae and their Gymnodinium splendens prey are commonly found nearshore (Lasker, 1981), the model will also incorporate the contribution of tidal mixing to $\mathrm{K}_{\mathrm{v}}$ in shallow water columns.

One would also like to investigate the effect of winddriven deepening of the mixed layer on overall water column productivity and how this relates to larval fish 
survival further offshore. Entrainment of new nutrients into the mixed layer would enhance primary production. Entrainment may not significantly increase the production by dinoflagellates which can vertically migrate below the pycnocline at night to acquire nutrients and then rise toward the surface to photosynthesize during the day (Cullen and Horrigan, 1981, and references therein). However, enhanced primary production should ultimately lead to increased secondary production and higher concentration of prey items of larval fish such as copepod nauplii, ciliates and tintinnids. A more complex 'ecosystem type' model is required to simulate these effects (Wroblewski and Richman, in prep.).

The formulation of growth of prey in the simple model presented above limits the time of forward integration for which the model is valid. While the initial patch is diffused, because there is no limitation to growth of $\mathrm{P}^{\prime}$, the total quantity of $\mathrm{P}^{\prime}$ continually increases. There is no 'poison area' surrounding the patch as in the Kierstead and Slobodkin (1953) model to keep the total $\mathrm{P}^{\prime}$ small. Thus, results of the present model concerning the response of the prey patch about the critical wavenumber $\mathrm{k}$ are valid only for a day or two. This limitation can be alleviated by including resource supply kinetics for P' (e.g. Michaelis-Menton nutrient dynamics or food-limited microzooplankton growth) in the model.

\section{CONCLUSIONS}

In spite of its limitations, this simple model gives insight into the problem of larval anchovy survival in a vertical mixing environment. We have shown that the critical thickness of the layer of food (feebly swimming dinoflagellates or microzooplankton) within the mixed layer is $\mathrm{H}_{\mathrm{c}}=2 \pi\left(\mathrm{K}_{\mathrm{V}} /\left(\mathrm{V}_{\mathrm{m}}-\mathrm{R}_{\mathrm{m}} \lambda\right)\right)^{1 / 2}$. Only if the stratum is thicker than $\mathrm{H}_{\mathrm{c}}$ can the prey grow fast enough to maintain their concentration despite losses due to zooplankton grazing and turbulent diffusion. Diffusivities of order $1 \mathrm{~cm}^{2} \mathrm{~s}^{-1}$ in the mixed layer can dissipate strata of slow growing prey about $10 \mathrm{~m}$ thick. Since light winds can generate these diffusivities, suitable concentrations of food for anchovy larvae are unlikely to exist in well mixed water columns except under calm wind conditions. However this is not true if the prey has a swimming ability which allows it to aggregate. The dinoflagellate Gymnodinium splendens, a suitable food for young anchovy larvae, has this ability. Diffusivities of the order $10 \mathrm{~cm}^{2} \mathrm{~s}^{-1}$ are required to disperse layers of these dinoflagellates. Thus anchovy larvae could find sufficient concentrations of this type of food in shallow, well mixed waters even during moderate wind conditions.
Further offshore, where dinoflagellates and microzooplankton are associated with density discontinuities near the base of the mixed layer, vertical diffusivities are reduced due to the stratification. Strong winds are required to disperse these food strata. If the food patch does dissipate during a violent storm, e.g. as observed by Lasker in April, 1974, the decrease in growth rate of the anchovy larvae could quickly lead to a higher mortality rate.

The present model synthesizes laboratory experiments and field observations of the feeding environment of larval anchovy into a theoretical framework. It serves as a stepping stone for further model development. More realistic but complex simulation models whose predictions can be directly compared to observations during wind events are needed for continued testing of hypotheses.

Acknowledgements. This research was supported by the Natural Sciences and Engineering Research Council of Canada, Strategic Grant No. G0358. I wish to thank Drs. James Richman, Carl Boyd, Chris Garrett, Gordon Riley and Ms. Ingrid Peterson for discussions and suggestions, and also the anonymous reviewers of my manuscript for valuable criticism. I was originally motivated to undertake this modeling study while attending the UN/FAO sponsored 'Workshop on the Effects of Environmental Variation on the Survival of Larval Pelagic Fishes' held in Callao, Peru in April, 1980. More recent encouragement came from Dr. Reuben Lasker as he accepted the A. G. Huntsman award in Halifax, Nova Scotia in November, 1983 for his contributions to elucidating the mechanism controlling year-class strength in the California anchovy.

\section{LITERATURE CITED}

Arthur, D. K. (1976). Food and feeding of larvae of three fishes occurring in the California Current, Sardinops sagax, Engraulis mordax, and Trachurus symmetricus. Fish. Bull. U. S. 74: $517-530$

Beers, J. R., Stewart, G. L. (1970). Numerical abundance and estimated biomass of microzooplankton. In: Strickland, J. D. H. (ed.) The ecology of the plankton off La Jolla, California, in the period April through September, 1967. Bull. Scripps Inst. Oceanogr. 17: 67-87

Beyer, J. E., Laurence, G. C. (1980). A stochastic model of larval fish growth. Ecol. Model. 8: 109-132

Blaxter, J. H. S., Hunter, J. R. (1982). The biology of the clupeoid fishes. Adv. mar. Biol. 20: 1-222

Chester, A. J. (1978). Microzooplankton relative to a subsurface chlorophyll maximum layer. Mar. Sci. Comm. 4: 275-292

Cullen, J. J., Eppley, R. W. (1981). Chlorophyll maximum layers of the Southern California Bight and possible mechanisms of their formation and maintenance. Oceanol. Acta 4: 23-32

Cullen, J. J., Horrigan, S. G. (1981). Effects of nitrate on the diurnal vertical migration, carbon to nitrogen ratio, and the photosynthetic capacity of the dinoflagellate Gymnodinium splendens. Mar. Biol. 62: 81-89

Cushing, D. H. (1983). Are fish larvae too dilute to affect the density of their food organisms? J. Plankton Res. 5: $847-854$ 
Hjort, J. (1914). Fluctuations in the great fisheries of northern Europe viewed in the light of biological research. Rapp. P.-v. Reun. Cons. Perm. int. Explor. Mer 20: 1-228

Houde, E. D., Schekter, R. C. (1981). Growth rates, rations and cohort consumption of marine fish larvae in relation to prey concentrations. In: Lasker, R., Sherman, K. (ed) The early life history of fish. Rapp. P.-v. Reun. Cons. int. Explor. Mer 178: 441-453

Hunter, J. R. (1982). Predation and recruitment. In: Rothschild, B. J., Rooth, C. G. H. (ed.) Fish ecology, III. University of Miami, Tech. Rep. No. 82008, p. 172-209

Hunter, J. R., Thomas, G. L. (1974). Effect of prey distributions and density on the searching and feeding behavior of larval anchovy Engraulis mordax Gerard. In: Blaxter, J. H. S. (ed.) The early life history of fish. Springer-Verlag, Berlin, p. $559-574$

Ivlev, V. S. (1955). Experimental ecology of the feeding of fishes. Pischepromizdat, Moscow. Transl. from Russian by D. Scott, Yale University Press, New Haven, Connecticut, 1961

Kiefer, D. A., Lasker, R. (1975). Two blooms of Gymnodinium splendens, an unarmored dinoflagellate. Fish. Bull. U. S. 73: 675-678

Kierstead, H., Slobodkin, L. B. (1953). The size of water masses containing plankton blooms. J. mar. Res. 12: 141-147

Kullenberg, G. E. B. (1971). Vertical diffusion in shallow waters. Tellus 23: 129-135

Kullenberg, G. E. B. (1976). On vertical mixing and the energy transfer from the wind to the water. Tellus 28: 159-165

Kullenberg, G. E. B. (1978). Vertical processes and the vertical-horizontal coupling. In: Steele, J. H. (ed.) Spatial pattern in plankton communities. Plenum Press, New York, p. 43-71

Lasker, R. (1975). Field criteria for survival of anchovy larvae: the relation between inshore chlorophyll maximum layers and successful first feeding. Fish. Bull. U. S. 73: 453-462

Lasker, R. (1978). The relation between oceanographic conditions and larval anchovy food in the California Current: identification of factors contributing to recruitment failure. Rapp. P.-v.-Réun. Cons, int. Explor. Mer 173: 212-230

Lasker, R. (1981). Factors contributing to variable recruitment of the northern anchovy (Engraulis mordax) in the California current: contrasting years, 1975 through 1978. Rapp. P.-v. Réun. Cons. int. Explor. Mer 178: 375-388

Lasker, R., Feder, H. M., Theilacker, G. H., May, R. C. (1970). Feeding, growth and survival of Engraulis mordax larvae reared in the laboratory. Mar. Biol. 5: 345-353

Lasker, R., Smith, P. E. (1977). Estimates of the effects of environmental variation in the eggs and larvae of the northern anchovy. Calif. Coop. Oceanic. Fish. Invest. Rep. 19: $128-137$

Lasker, R., Zweifel, J. R. (1978). Growth and survival of first- feeding northern anchovy larvae (Engraulis mordax) in patches containing different proportions of large and small prey. In: Steele, J. H. (ed.) Spatial pattern in plankton communities. Plenum Press, New York, p. 329-354

Laurence, G. C. (1977). A bioenergetic model for the analysis of feeding and survival potential of winter flounder, Pseudopleuronectes americanus, larvae during the period from hatching to metamorphosis. Fish. Bull. U. S. 75: $529-546$

O'Connell, C. P., Raymond, L. P. (1970). The effect of food density on survival and growth of early post yolk-sac larvae of the northern anchovy (Engraulis mordax Girard) in the laboratory. J. exp. mar. Biol. Ecol. 5: 187-197

Okubo, A. (1972). A note on small organism diffusion around an attractive center: a mathematical model. J. oceanogr. Soc. Japan 28: 1-7

Owen, R. W. (1981). Microscale plankton patchiness in the larval anchovy environment. In: Lasker, R., Sherman, K., (ed.) The early life history of fish. Rapp. P.-v. Réun. Cons. int. Explor. Mer 178: 364-268

Parrish, R. H., Nelson, C. S., Bakun, A. (1981). Transport mechanisms and reproductive success of fishes in the California Current. Biol. Oceanogr. 1: 175-203

Pomeroy, L. R. (1974). The ocean's food web, a changing paradigm. Biol. Sci. 24: 499-504

Rothschild, B. J., Rooth, C. G. H. (ed.) (1982). Fish ecology III a foundation for REX - a recruitment experiment. University of Miami Tech. Rep. No. 82008

Sheldon, R. W., Sutcliffe, W. H., Jr. (1978). Generation times of $3 \mathrm{~h}$ for Sargasso Sea microplankton determined by ATP analysis. Limnol. Oceanogr. 23: 1051-1054

Smith, P. E., Lasker, R. (1978). Position of larval fish in an ecosystem. Rapp. P.-v. Réun. Cons. int. Explor. Mer 173: $77-84$

Thomas, W. H., Dodson, A. N., Linden, C. A. (1973). Optimum light and temperature requirements for Gymnodinium splendens, a larval fish food organism. Fish. Bull. U. S. 71: 599-601

Vlymen, W. J. (1977). A mathematical model of the relationship between larval anchovy (Engraulis mordax) growth, prey microdistribution and larval behavior. Environ. Biol. Fish. 2: 211-233

Walsh, J. J., Whitledge, T. E., Esaias, W. E., Smith, R. L., Huntsman, S. A., Santander, H., de Mendiola, B. R. (1980). The spawning habitat of the Peruvian anchovy, Engraulis ringens. Deep Sea Res. 27: 1-27

Weihs, D. (1980). Energetic significance of changes in swimming modes during growth of larval anchovy, Engraulis mordax. Fish. Bull. U. S. 77: 597-604

Wroblewski, J. S. (1983). The role of modeling in biological oceanography. Ocean Sci. Engng 8: 245-285

Wroblewski, J. S., O'Brien, J. J., Platt, T. (1975). On the physical and biological scales of phytoplankton in the ocean. Mém. Soc. r. Sci. Liège 6 (VII): 43-57 